\title{
PENGARUH MODEL PEMBELAJARAN BERBASIS MASALAH TERHADAP KETERAMPILAN BERPIKIR KREATIF DALAM PEMBELAJARAN IPS KELAS IV SEKOLAH DASAR
}

\author{
Ahmad Muzakki Alfahmi ${ }^{1}$, Warsono ${ }^{2}$, Waspodo Tjipto Subroto ${ }^{3}$ \\ ${ }^{1}$ Mahasiswa Program Pascasarjana, Prodi Pendidikan Dasar, Universitas Negeri Surabaya, \\ ${ }^{2 \& 3}$ Dosen Pascasarjana, Prodi Pendidikan Dasar, Universitas Negeri Surabaya \\ e-mail: ahmad.10090@gmail.com
}

Received : November 2018

Reviewed : Desember 2018

Accepted : Januari 2019

Published : Januari 2019
ABSTRACT

In this study, researchers used a type of experimental research. Experimental research conducted because there is whether or not to examine the relationship between the causal variables are tied and free through model-based learning problems about creative thingking. The subject of research is the student class IVB as class experiments, and class IVA as a control class. Each class respectively amounted to 20 students. The results of hypothesis testing retrieved results $t$ count of 9, 327dan t table with signification value 0,05 is 2,086. Thus the value $t$ count earned value greater than t table (9,327 > 2, 086). Based on those results, then the hypothesis is accepted means there is significant influence between the free variable problem based learning $(X)$ towards creative thinking bound variable $(Y)$ grade IV elementary school.

Keyword: Problem Based Learning, Creative Thinking, Social Studies.

\section{ABSTRAK}

Pada penelitian ini, peneliti menggunakan jenis penelitian eksperimen. Penelitian eksperimen dilakukan karena untuk meneliti ada tidaknya hubungan sebab akibat antara variable terikat dan bebas melalui model pembelajaran berbasis masalah terhadap keterampilan berpikir kreatif. Subjek penelitian adalah siswa kelas IVB sebagai kelas eksperimen, dan kelas IVA sebagai kelas kontrol. Setiap kelas masingmasing berjumlah 20 siswa. Hasil pengujian hipotesis diperoleh hasil t hitung sebesar 9,327dan $t$ tabel dengan nilai signifikansi 0,05 adalah 2,086. Dengan demikian nilai t hitung yang didapat lebih besar dari nilai t tabel $(9,327>2,086)$. Berdasarkan hasil tersebut, maka hipotesis diterima artinya terdapat pengaruh yang signifikan antara variable bebas pembelajaran berbasis masalah (X) terhadap variable terikat berpikir kreatif (Y) siswa kelas IV.

Kata Kunci: Pembelajaran Berbasis Masalah, Kemampuan Berpikir Kreatif, Ilmu Pengetahuan Sosial.

\section{PENDAHULUAN}

Mewujudkan pendidikan yang baik diperlukan proses belajar mengajar yang optimal dan kondusif. Pembelajaran di sekolah dianggap sebagai kegiatan mentransfer ilmu pengetahuan dari guru kepada murid. Seorang guru dianggap sebagai sumber informasi yang mengetahui segalanya, sedangkan siswa sebagai peserta didik yang hanya duduk diam, menunggu, dan menyerap informasi dari guru.

Seorang guru harus selalu menciptakan dan mengatur lingkungan belajar yang menarik bagi peserta didik. Terciptanya lingkungan belajar yang menarik bagi siswa dapat memberikan proses pembelajaran yang aktif dan menyenangkan sehingga siswa dapat mengikuti pembelajaran dengan penuh semangat, dan materi yang diajarkan dapat diterima dengan baik. Salah satu bagian penting dari kegiatan belajar pada materi Ilmu Pengetahuan Sosial adalah mengembangkan kesadaran tentang belajar, dengan kata lain para siswa harus membiasakan diri untuk memahami seberapa banyak kompetensi dari pokok bahasan yang telah dipelajarinya. Sardjiyo (2007:129) mengemukakan dalam tujuan mata pelajaran ilmu sosisal 
salah satunya siswa diwajibkan memiliki kemampuan dasar untuk berpikir logis dan kritis, rasa ingin tahu, inkuiri, memecahkan masalah, dan keterampilan dalam kehidupan sosial. Sehingga dalam pelaksanaan pembelajaran guru dapat memberikan kesempatan kepada siswa untuk dapat berpikir, mencari tahu, dan tidak takut dalam proses pembelajaran berlangsung.

Berdasarkan hasil observasi yang dilakukan saat proses pembelajaran IPS pada kelas IV di SDN Kedunggede Mojokerto, siswa hanya mendengar materi yang dijelaskan oleh guru, siswa kurang aktif bertanya, dan rata-rata siswa tidak dapat menjawab pertanyaan ketika guru memberikan pertanyaan lisan. Beberapa siswa yang menjawab pertanyaan dari guru, jawaban siswa hanya sesuai apa yang ada di dalam buku dan bersifat hafalan sedangkan siswa yang lain hampir sama dengan siswa lain dalam artian jawaban ikut-ikutan dengan temannya. Terlihat bahwa siswa kurang aktif dan kreatif dalam kemampuan berpikirnya. Pada saat pembelajaran guru menekankan pada hafalan materi yang telah diajarkan oleh guru. Selain itu, kurang terlibatnya anak pada aktivitas yang lebih konkret dalam memperoleh pengetahuan. Hal demikianlah yang membuat siswa kurang mendalami materi yang harus dicapai pada saat pembelajaran berlangsung. Sehingga aktivitas belajar tidak bermakna karena lebih menekankan hasil belajar dari pada proses belajar akibatnya secara tidak langsung membebani peserta didik. Hal ini mengisyaratkan terabaikannya kreativitas dalam mengungkapkan ide atau gagasan yakni dengan membatasi perkembangan kemampuan berpikir dan pengetahuan baru yang diperoleh siswa. Hal demikian tidak sejalan dengan pendapat Pehkonen (dalam Siswono, 2008:20-21) memandang berpikir kreatif sebagai suatu kombinasi dari berpikir logis dan berpikir divergen yang didasarkan pada intuisi tetapi masih dalam kesadaran.

Hasil wawancara dengan siswa kelas IV, siswa juga tidak pernah melakukan tanya jawab dengan guru mengenai materi IPS. Menurut salah satu siswa, materi pelajaran IPS kurang menarik karena belajar IPS seperti mendengarkan orang ceramah saja, berbeda dengan matematika yang melibatkan siswa untuk menghitung sedangkan pelajaran IPS banyak hafalan. Dapat dikatakan bahwa pelajaran IPS kurang diminati siswa. Informasi yang didapat dari observasi bahwa guru kurang menggunakan model, metode atau pendekatan pembelajaran yang bervariasi, guru lebih sering menggunakan model konfensional yakni metode ceramah. Guru mengatakan bahwa dengan metode tersebut dapat menyeleseikan target materi yang harus diselesaikan dalam satu semester. Penggunaan bermacam-macam model pembelajaran yang baru dikhawatirkan dapat menghambat target materi akhir semester karena banyak waktu digunakan untuk merencanakan model pembelajaran tersebut. Selama ini guru beranggapan bahwa pelajaran IPS hanya bersifat hafalan sehingga cukup hanya dengan menulis, membaca, menerangkan, dan soal-soal. Metode ceramah tersebut tidak dapat mengembangkan kemampuan berpikir kreatif siswa. Kemampuan berpikir kreatif siswa juga bergantung pada guru karena guru juga dituntut untuk lebih kreatif dalam memberikan stimulus pada siswa dengan menggunakan berbagai macam model, metode, atau pendekatan pembelajaran.

Hal ini kurang sejalan dengan tujuan pendidikan IPS dalam kurikulum 2006, antara lain adalah sebagai berikut: (1) mengenal konsep-konsep yang berkaitan dengan kehidupan masyarakat dan lingkungannya, (2) memiliki kemampuan dasar untuk berpikir logis dan kritis, rasa ingin tahu, inkuiri, memecahkan masalah, dan keterampilan dalam kehidupan sosial, (3) memiliki komitmen dan kesadaran terhadap nilai-nilai sosial dan kemanusiaan, (4) memiliki kemampuan berkomunikasi, bekerjasama dan berkompetesi dalam masyarakat yang majemuk di tingkat lokal, nasional, dan global. Kemampuan berpikir ini merupakan salah satu aspek yang terpenting dalam mengembangkan potensi seseorang. Perkembangan keterampilan berpikir sejalan dengan pemahaman dan kemampuan analisis, semakin bertambah usia siswa maka semakin tinggi tingkat pemahaman dan analisisnya.

Menurut Sapariya (2009:86) kemampuan berpikir kreatif dapat diterapkan dalam proses pembelajaran dengan tujuan untuk mendorong siswa untuk mengemukakan jawaban sebanyak-banyaknya sesuai dengan fokus masalah yang diajukan atau diberikan oleh guru melalui eksperimen atau penemuan. Keterampilan berpikir kreatif akan mampu memunculkan gagasan baru atau mengembangkan ide dari yang sudah ada sebelumnya. Ide tersebut muncul dari pengalaman yang telah dialami sebelumnya. Selain itu keterampilan berpikir kreatif menunjang siswa ketika dihadapkan dalam suatu permasalahn yang harus dipecahkan dari berbagai sudut pandang. Hal tersebut sejalan dengan pendapat Awang (2008:335) Creative thinking will make students move "sideways" to try different perceptions, different concepts, different points of entry. Dengan demikian bahwa berpikir kreatif akan membuat siswa beralih untuk mencoba persepsi yang berbeda, konsep yang berbeda dan membuat poin yang berbeda. Aziz (2012:39) menambahkan jika dikaitkan dengan pemecahan masalah, berpikir merupakan sebuah proses mental yang melibatkan beberapa manipulasi 
pengetahuan seperti menghubungkan pengertian yang satu dengan pengertian lainnya dalam sistem kognitif yang diarahkan untuk menghasilkan solusi dalam memecahkan masalah.

Menurut Santrock (2008) berpikir adalah memanipulasi atau mengolah dan mentransformasi informasi dalam memori. Berpikir ini sering dilakukan untuk membuat konsep, berpikir secara kritis, membuat keputusan, bernalar, berpikir kreatif dan memecahkan masalah. Oleh karena itu kemampuan berpikir ini sangat diperlukan oleh setiap siswa. Upaya untuk meningkatkan kemampuan berpikir, guru dapat melatih siswa dengan menunjukkan cara berpikir melalui semua mata pelajaran yang ada di sekolah. Dengan memberikan contoh masalahmasalah cara berpikir yang baik, memberikan pertanyaan berupa masalah yang menuntut siswa untuk dapat memanfaatkan proses keterampilam berpikir kreatif. Hal ini sejalan dengan pendapat Susanto (2012:110) berpikir kreatif merupakan sebuah proses menjadi sensitif atau sadar terhadap masalah-masalah, kekurangan, dan celahcelah di dalam pengetahuan yang untuk tidak ada solusi yang dipelajari, membawa serta informasi yang ada dari gudang memori atau sumber-sumber eksternal, mengidentifikasi kesulitan atau mengidentifikasi unsurunsur yang hilang, mencari solusi-solusi, menduga, menciptakan alternatif-alternatif tersebut, penyempurnaan dan akhirnya mengomunikasikan hasil-hasilnya. Torrance (dalam Elvira, 2010:1) menambahkan bahwa berpikir kreatif adalah a process of becoming sensitive to problems, gaps in knowledge, missing elements, and disharmonies. Sedangkan Guilford (dalam Salim, 2014:518) has identified four central components of creative thinking skills (divergent thinking) that include: fluency, flexibility, originality and elaboration.

Dengan kata lain pembelajaran kreatif adalah dicirikan dengan hal baru, dibentuk melalui suatu proses pemikiran yang baru. Memiliki kemampuan untuk meciptakan, dirancang untuk mensimulasikan imajinasi, sehingga melalui pengalaman siswa di kelas maka akan tercipta kemampuan berpikir.

Hal demikian dapat tercapai apabila guru dalam pengolahan pembelajaran dengan memilih model pembelajaran yang melibatkan siswa untuk aktif dan dapat memunculkan kemampuan berpikir siswa. Banyak pemilihan model pembelajaran yang kreatif dan inovatif, namun peneliti lebih memilih tentang adanya pengaruh model pembelajaran berbasis masalah, dalam mengaplikasaikan kegiatan tersebut disesuaikan dengan materi pelajaran yang akan diberikan. Dalam penelitian ini model yang digunakan adalah model pembelajaran berbasis masalah.

Model pembelajaran berbasis masalah merupakan proses pembelajaran yang menghadapkan siswa pada suatu masalah sebelum memulai proses pembelajaran. Siswa dihadapkan pada suatu masalah yang nyata yang memacunya untuk meneliti, menguraikan dan mencari penyelesaiannya. Pembelajaran berbasis masalah sangat berkaitan dengan realitas kehidupan nyata siswa, sehingga siswa belajar tidak hanya pada wilayah pengetahuan, tetapi juga mengalami dan merasakan. Kemampuan guru dibutuhkan dalam mengajar konsep-konsep pembelajaran dengan mendekatkan siswa kepada masalah yang ada dalam kehidupan sosial, sehingga siswa peka terhadap lingkungan sosial yang ada di masyarkat, memiliki sifat mental positif dan terampil dalam menghadapi masalah sehari-hari dalam kehidupan pribadi maupun masyarakat.

Seringkali guru menggunakan salah satu model atau metode dalam pembelajaran. Hal tersebut juga dilakukan saat guru mengajarkan pelajaran IPS. Padahal pelajaran IPS tidak bisa hanya menggunakan satu model atau metode pembelajaran saja. Model pembelajaran atau metode harus disesuaikan dengan materi, situasi dan kondisi belajar siswa, usia siswa, ketersediaan media, tingkatan kelas serta tujuan pembelajara yang hendak dicapai.

Perhatian peneliti dalam permasalahan yang terjadi adalah proses pembelajaran guru yang masih menggunakan metode ceramah saja. Pembelajaran terkesan hanya sebagai transfer ilmu belaka kepada siswa, sehingga membuat siswa menjadi pasif. Hal tersebut mengungkapkan bahwa metode ceramah mengesampingkan keaktifan siswa dalam pembelajaran.

Alternatif jalan keluar yang dapat digunakan untuk meningkatkan keterampilan berpikir kreatif siswa adalah merubah cara mengajar yang awalnya menggunakan metode ceramah saja dengan mengganti model pembelajaran yang dapat merubah kebiasaan siswa yang awalnya menerima informasi dari guru menjadi ke arah pembelajaran yang dapat melatih partisipasi aktif siswa sehingga dapat meningkatkan keterampilan berpikir kreatif. Model pembelajaran tersebut adalah model pembeajaran berbasis masalah.

Pada pembelajaran berbasis masalah, tugas seorang guru adalah memberikan sebuah perlakuan yang dapat menghantarkan siswanya untuk terjun langsung dalam proses pembelajaran. Sehingga siswa menjadi lebih aktif dalam pembelajaran. Sesuai dalam karakteristik pembelajaran berbasis masalah mengharuskan siswa untuk melakukan investigasi autentik yang berusaha menemukan solusi riil. Demikian pada langkah-langkah pembelajaran 
berbasis masalah yang menuntut siswa untuk memecahkan masalah yang telah disediakan.

Pembelajaran berbasis masalah menjadikan lingkungan sebagai bahan pembelajaran. Ruang lingkup pembelajaran IPS menurut KTSP 2006 salah satunya adalah lingkungan yang mempelajarai gejala-gejala atau masalah-masalah yang ada di lingkungan sekitar, serta faktor pendorong keterampilan berpikir kreatif salah satunya adalah lingkungan yang mendukung. Dengan pembelajaran berbasis masalah akan membuat siswa memunculkan gagasan-gagasannya dalam mencari dan menemukan solusi, dalam pencarian tersebut indikator keterampilan berpikir kreatif akan muncul dengan sendirinya yakni berpikir lancar, berpikir luwes dan berpikir seacara orisinil. Jadi pembelajaran berbasis masalah yang menggunakan lingkungan sebagai bahan pembelajaran sangat berhubungan erat sekali pada proses pembelajaran. Hal ini diperkuat pendapat Banks bahwa berpikir kompleks terdiri dari pemecahan masalah, berpikir kreatif, berpikir kritis dan pengambilan keputusan, yang merupakan proses yang sering berubungan satu sama lain. Sehingga model pembelajaran berbasis masalah berhubungan erat sekali karena di dalam model pembelajaran berbasis masalah siswa diminta untuk menemukan jawaban berdasarkan masalah yang telah disediakan.

\section{METODE}

Penelitian ini menggunakan jenis penelitian eksperimen. Penelitian eksperimen dilakukan untuk meneliti ada tidaknya hubungan sebab akibat antar variabel (antara pembelajaran berbasis masalah dan berpikir kreatif). Penelitian eksperimen ini melibatkan dua kelompok yaitu kelompok control dan kelompok eksperimen. Pada kelas kontrol akan menerapkan pembelajaran konvensional (tidak memberikan perlakuan) dan pada kelas eksperimen akan menerapkan pembelajaran berbasis masalah (mendapatkan perlakuan). Penelitian ini menggunakan desain pretest-posttest control group. Desain penelitian dapat dilihat pada bagan berikut ini:

Tabel 1.

Pretest-Postest Control Group Desain

\begin{tabular}{lcccc}
\hline Treatment group & $R$ & $O 1$ & $X$ & $O 2$ \\
\cline { 2 - 5 } Control group & $R$ & $O 3$ & $O 4$ \\
\hline \multicolumn{2}{c}{ (Sukardi, $2003: 185)$}
\end{tabular}

Alokasi waktu yang digunakan untuk penelitian ini adalah selama semester genap 2015/2016. Tempat penelitian berada di SDN Kedunggede Mojokerto.
Pemilihan sekolah tersebut sebagai tempat penelitian karena: (1) sekolah bersifat terbuka dan mau menerima adanya penelitian ini yang bertujuan untuk inovasi pendidikan, (2) kesediaan dari pihak sekolah untuk bekerjasama dalam kegiatan penelitian, dan (3) memiliki kelas parallel sehingga mudah dalam mengelompokkan kelas eksperimen dan kelas kontrol.

Subjek dalam penelitian ini adalah kelas IVB sebagai kelas eksperimen yang berjumlah 20 siswa dan kelas IVA sebagai kelas kontrol yang berjumlah 20 siswa.

Langkah-langkah yang akan dilakukan pada penelitian ini adalah sebagai berikut:

1. Tahap Persiapan: melakukan studi literatur tentang pembelajaran berbasis masalah, melakukan observasi lapangan, mennetukan kelas yang akan dijadikan subyek penelitian, menentukan materi yang akan diajarkan saat penelitian, dan menyususn perangkat pembelajaran dan instrument peneliian.

2. Tahap Pelaksanaan: memberikan tes awal kepada kelas ekserimen dan kelas kontrol, menerapkan pembelajaran berbasis masalah pada kelas eksperimen dan pembelejaran konvensional pada kelas kontrol, dan memberikan test akhir pada kelas eksperimen dan kelas kontrol.

3. Tahap Pengolahan Data: mengolah dan menganalisis data hasil penelitian, dan melakukam uji hipotesis..

Sebelum dilakukan penelitian dilaksanakan uji terbatas pada kelas diluar sampel yang bertujuan untuk mengetahui kevalidan dan reliabilitas intrumen penelitian. Menurut Azwar (1996:74) validitas berasal dari kata validity yang mempunyai arti sejauh mana ketepatan dan kecermatan suatu instrument pengukur (tes) dalam melakukan fungsi ukurnya. Sesudah instrument selesei disusun lalu diuji cobakan kepada responden di luar sampel. Reliabilitas soal tes keterampilan berpikir kreatif dalam menyelesiakan masalah di lingkungan sekitar merupakan kemampuan soal tes yang dibuat mampu memberikan nilai atau hasil yang tetap (konsisten) jika diterapkan dalam situasi dan kondisi yang sama untuk mengukur keterampilan berpikir kreatif siswa. Untuk menghitung uji reliabilitas item soal seluruh tes menggunakan rumus Alpha Cronbach's dengan uji reliability analysis dengan bantuan program SPSS untuk menganalisis reliabilitas. Adapun kriteria yang digunakan untuk menentukan reliabilitas instrumen adalah nilai reliabilitas di atas 0,600 . Jadi, suatu instrumen dikatakan reliabel jika mempunyai nilai koefisien Alpha Cronbach's sekurang-kurangnya 0,600 
Pengumpulan data dalam penelitian ini dilakukan melalui teknik pemberian tes. Tes yang digunakan dalam peneltian ini berupa tes uraian. Tes dilakukan sebanyak dua tahap yakni tes sebelum proses pembelajaran (pretest) dan tes setelah proses pembelajaran (posttest). Pemberian tes tetap mengacu pada penggunaan model pembelajaran berbasis masalah dan kemampuan berpikir kreatif yang meliputi kelancaran, keluwesan, dan keaslian.

Teknik analisis yang digunakan dalam penelitian ini menggunakan teknik analisis deskriptif dan inferensial. Analisis data deskriptif bertujuan untuk menilai sejauh mana varaibel yang diteliti telah sesuai dengan tolok ukur yang sudah ditentukan, sedangkan analisis data inferensial digunakan untuk menguji hipotesis yang diajukan. Untuk menguji hipotesis yang diajukan untuk membuktikan pengaruh model pembelajaran berbasis masalah terhadap keterampilan berpikir kreatif pada kelas eksperimen dengan pembelajaran konfensional pada kelas kontrol. Pengujian tersebut menggunakan uji-t. Sebelum melakukan uji $\mathrm{t}$ terlebih dahulu di uji normalitas dan homogenitas.

\section{HASIL DAN PEMBAHASAN}

Menurut teori, model pembelajaran berbasis masalah adalah pembelajaran yang memposisikan siswa secara langsung untuk memecahkan masalah, sehingga dapat memberikan peluang pada peningkatan hasil keterampilan berpikir kreatif siswa. Keterlibatan aktif siswa dalam pembelajaran memiliki perang yang sangat penting dalam mengkonstruksi pemahaman dalam pikirannya.

Hasil validasi RPP yang telah divalidasi oleh validator menunjukkan nilai rata-rata 3,8 berarti kategori baik serta layak untuk digunakan meskiun masih ada beberapa aspek yang perlu dikembangkan lagi. Berikutnya hasil validasi tes berpikir kreatif menunjukkan nilai 3,5 berarti baik serta layak untuk digunakan dalam penelitian meskipun ada revisi.

Berdasarkan hasil validitas dapat diketahui bahwa semua butir soal dinayatakan valid. Data tersebut dapat dinyatakan valid apabila $t$ hitung $>\mathrm{t}$ tabel, sebaliknya dapat dikatakan tidak valid apabila $\mathrm{t}$ hitung $<\mathrm{t}$ tabel. Untuk melihat hasil $t$ hitung dapat dilihat pada lampiran perhitungan validitas melalui SPSS 19 . Sedangkan untuk melihat $\mathrm{t}$ tabel biasanya terdapat pada lampiran buku statistic untuk penelitian. Pada uji coba instrument diperoleh hasil validitas berpikir kreatif didapatkan $t$ hitung yang lebih besar dari $t$ tabel sehingga tes berpikir kreatif dinyatakan valid.
Setelah dinyatakan valid berikutnya adalah uji reliabilitas Berdasarkan tabel reliabilitas menunjukkan hasil data yang diolah dengan SPSS 19 dengan Cronbach Alpha sebesar 0,636. Jika dibandingkan dengan $t$ tabel sebesar 0.444, maka t hitung tersebut masih lebih besar. Pemerolehan hasil reliabilitas tersebut masuk kategori sangat tinggi. Jadi dapat disimpulkan bahwa soal tes berpikir kreatif tersebut reliabel.

Hasil uji normalitas data pada pretes di kelas eksperimen dan kelas kontrol dengan menggunakan SPSS 19. Untuk mengetahui tingkat normalitas data pada pretes dapat dilihat pada kolom Sig. Pada kolom Sig terdapat dua jenis Test of Normality yang pertama yakni KolmogorovSmirnova dan yang kedua yaitu Shapiro-Wilk. Kolmogorov-Smirnova digunakan apabila jumlah sampel lebih dari 50, sedangkan Shapiro-Wilk digunakan jika jumlah sampel kurang dari 50. Berdasarkan fungsi kegunaaan tersebut, dalam penelitian ini menggunakan Shapiro-Wilk karena jumlah sampel yang digunakan kurang dari 50 yakni ada 20 siswa. Hasil Shapiro-Wilk pada kolom sig pada Pretest kelas eksperimen yaitu 0,489 dengan df 20, dan lebih besar dari 0,05, dengan demikian data pretest kelas eksperimen berdistribusi Normal. Untuk data hasil pretes kelas kontrol menunjukkan nilai sig 0,122 dengan df 20 dan lebih besar dari 0,05, maka data hasil pretes pada kelas kontrol juga distribusi Normal.

Hasil uji normalitas pada postest dengan menggunakan bantuan program SPSS 19. Hasil ShapiroWilk pada kolom sig hasil posttest kelas eksperiman yakni 0,543 dengan df 20 dan lebih besar dari 0,05, dengan demikian data pretest kelas eksperimen berdistribusi Normal. Untuk data hasil postest kelas kontrol menunjukkan nilai sig 0,167 dengan df 20 dan lebih besar dari 0,05 , maka data hasil posttest pada kelas kontrol juga distribusi Normal

Selanjutnya hasil uji homogenitas pada data pretest diperoleh nilai sig 0,662 dan pada data posttest 0,450 , dari kedua data tersebut dapat dinyatakan homogeny karena lebih besar dari 0,05. Dari hasil perhitungan tersebut dapat dikatakan bahwa sebaran spada kedua kelas eksperimen dan kontrol adalah normal dan dikatakn homogen adalah kemampuan kedua kelas tersebut mempunyai kemampuan yang sama.

Setelah dinyatakan berdistribusi normal dan homogen berikutnya adalah dilakukan uji t/ uji beda. Hasil pengujianuji beda pada data preetes di kelas eksperimen maupun kelas kontrol. 
Tabel 2.

\begin{tabular}{|c|c|c|c|c|c|c|}
\hline \multicolumn{7}{|c|}{ Independent Samples Test } \\
\hline & & \multicolumn{2}{|c|}{$\begin{array}{l}\text { Levene's Test } \\
\text { for Equality of } \\
\text { Variances }\end{array}$} & \multicolumn{3}{|c|}{ t-test for Equality of Means } \\
\hline & & \multirow[t]{2}{*}{$\mathrm{F}$} & \multirow[t]{2}{*}{ Sig. } & \multirow[t]{2}{*}{$\mathrm{t}$} & $\begin{array}{l}95 \% \mathrm{Co} \\
\text { Interval } \\
\text { Differen }\end{array}$ & $\begin{array}{l}\text { ence } \\
\text { e }\end{array}$ \\
\hline & & & & & Lower & Upper \\
\hline \multirow{2}{*}{$\begin{array}{l}\text { hasil } \\
\text { pretes }\end{array}$} & $\begin{array}{l}\text { Equal } \\
\text { variances } \\
\text { assumed }\end{array}$ & .196 & .662 & 1.988 & -.048 & 5.348 \\
\hline & $\begin{array}{l}\text { Equal } \\
\text { variances not } \\
\text { assumed }\end{array}$ & & & 1.988 & -0.49 & 5.349 \\
\hline
\end{tabular}

Diperoleh nilai $\mathrm{t}$ hitung yakni 1,988, t hitung tersebut lebih kecil dari $\mathrm{t}$ tabel yang bernilai 2,086 sehingga t hitung < t tabel dan dapat dinyatakan bahwa tidak ada pengaruh pada kedua kelas tersebut sehingga $\mathrm{Ha}$ ditolak dan Ho diterima. Berikutnya pada hasil posttest pada kedua yakni kelas eksperimen dan kelas kontrol.

Tabel 3.

Independent Samples Test

\begin{tabular}{|c|c|c|c|c|}
\hline $\begin{array}{l}\text { Levene's } \\
\text { Equality } \\
\text { Variances }\end{array}$ & st for & \multicolumn{3}{|c|}{ t-test for Equality of Means } \\
\hline \multirow[t]{2}{*}{$\mathrm{F}$} & \multirow[t]{2}{*}{ Sig. } & \multirow[t]{2}{*}{$\mathrm{t}$} & \multicolumn{2}{|c|}{$\begin{array}{l}\text { 95\% Confidence } \\
\text { Interval of the } \\
\text { Difference }\end{array}$} \\
\hline & & & Lower & Upper \\
\hline \multirow[t]{2}{*}{.581} & .450 & 9.327 & 8.299 & 12.901 \\
\hline & & 9.327 & 8.294 & 12.906 \\
\hline
\end{tabular}

Diperoleh thitung sebesar 9,327 dengan signifikansi 0,000 . Dengan demikian nilai t hitung yang didapat lebih besar dari nilai ttabel $(9,327>2,086)$ sedangkan nilai sig lebih kecil dari $0,05 \quad(0,000<0,05)$. Berdasarkan hasil tersebut maka hipotesis diterima, artinya bahwa ada pengaruh yang signifikan antara variabel bebas pembelajaran berbasis masalah (X) terhadap variabel terikat berpikir kreatif (Y) siswa kelas IV SDN Kedunggede.

Nilai rata-rata berdasarkan nilai preetes keterampilan berpikir kreatif yang dicapai kelas eksperimen adalah 58,95 sedangkan rata-rata preetes kelas kontrol yaitu 56,30, tidak ada perbedan yang signifikan. Rata-rata posttest keterampilan berpikir kreatif kelas eksperimen yaitu 76,00 sedangkan rata-rata posttest kelas kontrol yaitu 65,40, terdapat perbedaan yang signifikan antara kelas eksperimen dan kelas kontrol pada hasil posttest.

Berdasarkan hasil pencapaian rata-rata nilai kelas eksperimen antara preetes dan posttest terjadi peningkatan dari 58,95 menjadi 76,00. Sedangkan untuk kelas kontrol dari rata-rata 56,30 menjadi 65,40. Sedangkan antara kelas eksperimen dan kelas kontrol rata-rata nilai preetes kelas eksperimen adalah 58,95, lebih besar apabila dibandingkan dengan rata-rata nilai pretest kelas kontrol yang bernilai 56,30 .

Dengan diskusi dalam model pembelajaran berbasis masalah, siswa akan terjalin suatu komunikasi dengan saling berbagi ide atau pendapat dengan teman dan mencari pemecahan masalah mereka sendiri dengan mengonstruk pengetahuan mereka. Jadi, siswa akan terlatih untuk menyelesikan masalah yag ada pada lingkungan sekitar, saling menghargai pendapat teman, dan berani berinteraksi dengan teman-temannya sehingga akan mengembangkan keterampilan berpikir kreatif mereka. Pada hasil uji t dapat dilihat dan dipahami bahwa hasil analisis t tes diperoleh thitung sebesar 9,327 dan jauh lebih besar dari ttabel dan diperoleh nilai signifikansi sebesar 0,000 dan lebih kecil dari 0,05. Dengan demikian dapat disimpulkan bahwa dengan tingginya thitung dan nilai signifikansi lebih kecil dari 0,05, maka penelitian ini berhasil menolak Ho dan menunjukkan bahwa Ha terbukti benar.

\section{PENUTUP \\ Simpulan}

Berdasarkan hasil analisis dapat disimpulkan bahwa model pembelajaran berbasis masalah berpengaruh terhadap keterampilan berpikir kreatif siswa pada pembelajaran IPS siswa kelas IV Sekolah Dasar. Hal tersebut dapat dilihat dari hasil analisis data degan uji beda pada data preetes kelas eksperimen dan kelas kontrol yang telah dihitung diperoleh nilai $\mathrm{t}$ hitung sebesar 1,988 hal tersebut lebih kecil dari $\mathrm{t}$ tabel 2,086 sehingga dapat dinyatakan bahwa tidak ada pengaruh pada data preetes. Selanjutnya diberikan perlakuan pada kelas eksperimen dan tidak diberikan perlakuan pada kelas kontrol.

Perlakuan pada kelas eksperimen adalah dengan menggunakan model pembelajaran berbasis masalah, sedangkan pada kelas kontrol adal metode konvensional atau metode ceramah. Setelah dilakukan perhitungan pada data posttest diperoleh thitung sebesar 9,327 lebih besar dari t tabel 2,086. Maka dari itu, dapat disimpulkan bahwa ada perbedaan keterampilan berpikir kreatif siswa dalam belajar dengan menggunakan model pembelajaran berbasis 
masalah dibandingkan dengan pembelajaran menggunakan pembelajaran konvensional.

Terdapat perbedaan yang signifikan keterampilan berpikir kreatif antara kelas kontrol dan kelas eksperimen siswa kelas IV Sekolah Dasar. Dari hasil tersebut dapat disimpulkan bahwa terdapat perbedaan hasil nilai pada kelas eksperimen dan kelas kontrol, maka terdapat pula pengaruh. Sehingga model pembelajaran berbasis masalah berpengaruh terhadap keterampilan berpikir kreatif siswa, hal tersebut menunjukkan bahwa semakin meningkat nilai pembelajaran berbasis masalah, maka berpikir kreatif siswa kelas IV Sekolah Dasar juga akan mengalami peningkatan.

\section{Saran}

Berdasarkan hasil penelitian yang telah dilakukan, model pembelajaran berbasis masalah perlu diimplementasikan di dalam kelas karena dapat meningkatan keterampilan berpikir kreatif siswa. Pembelajaran sebaiknya dirancang sesuai kebutuhan dan kemampuan individu siswa. Agar pembelajaran menarik, guru dapat menggunakan media yang dapat menarik perhatian siswa dan dapat meningkatkan kemampuan berpikir siswa sehingga hasil belajar siswa juga diharapkan menjadi lebih baik.

\section{DAFTAR PUSTAKA}

Arends, Richard, I. (2008). Learning To Teach Belajar Untuk Mengajar (Edisi Ketujuh: Buku Dua). Yogyakarta: Pustaka Pelajar.

(2012) Learnig to Teach, Ninth Edition. New York: McGraw-Hill.

Arikunto, Suharsimi. (1989). Manajemen Penelitian. Jakarta: Departemen Pendidikan dan Kebudayaan P2LPTK.

Awang, Halizah and Ishak Ramly. (2008). "Creative Thinking Skill Approach Through ProblemBased Learning: Pedagogy and Practice in the Engineering Classroom". World Academy of Science, Engineering and Technology International Journal of Social, Behavioral, Educational, Economic, Business and Industrial Engineering. Vol.2 No.4. pp. 334-339.

Aziz, Abdul Saefudin. (2012). "Pengembangan Kemampuan Berpikir Kreatif Siswa dalam Pembelajaran Matematika dengan Pendekatan Pendidikan Matematika Realistik Indonesia (PMRI)”. Al-Bidāyah. Vol 4 No 1. pp. 37-48.

Azwar, Saifudin. (1996). Tes Prestasi Fungsi dan Pengembangan Pengukuran Prestasi Belajar. Yogyakarta: Pustaka Belajar.
Bilgin Ibrahim, Erdal Senocak and Mustafa Snozbilir. (2009). "The Effect of Problem-Based Learning Instruction on University Students' Performance of Conceptual and Quantitative Problems in Gas Concept". Eurasia Journal of Mathematics, Science and Technology Education. pp. 153-164

DePorter, Bobbi. (2011). The 7 Biggest Teen Problems and How To Turn Them Into Strengths (Edriani Azardi, Trans). Bandung: Kaifa. (Original work published 2006)

Dimyati dan Mujiono. (1994). Belajar dan Pembelajaran. Jakarta: Direktorat Jendral Pendidikan Tinggi Departemen Pendidikan dan Kebudayaan.

Elvira, Maria De Caroli and Elisabetta Sagone. (2010). "Creative Thinking And Big Five Factors Of Personality Measured In Italian Schoolchildren”. Journal Faculty of Educational Science University of Catania, Italy.pp.1-12

Gunawan, Rudi. (2011). Pendidikan IPS: Filosofi, Konsep, dan Aplikasi. Bandung: Alfabeta.

Hassoubah, Zaleha, Izhab. (2004). Developing Creative \& Critical Thinking Skills (Cara Berpikir Kreatif \& Kritis). Bandung: Nuansa.

Herman, Tatang. (2007). “Pembelajaran Berbasis Masalah untuk Meningkatkan Kemampuan Berpikir Matematis Tingkat Tinggi Siswa Sekolah Menengah Pertama”. EDUCATIONIST. Vol.1 No.1. Januari 2007. pp. 47-56.

Ibrahim, Muslimin dan Mohammad Nur. (2005). Pengajaran Berdasarkan Masalah (Edisi 2). Surabaya: University Press.

Ibrahim, M. (2005). Pembelajaran Berdasarkan Masalah latar Belakang, Konsep Dasar, dan Contoh Implementasinya. Surabaya: Unesa University Press.

Julianto, dkk. (2011). Teori dan Implementasi ModelModel Pembelajaran Inovatif. Surabaya: Unesa University Press.

Kiki Efi Assriyanto, J.S. Sukardjo, dan Sulistyo Saputro. (2014). "Pengaruh Model Pembelajaran Berbasis Masalah Melalui Metode Eksperimen Dan Inkuiri Terbimbing Ditinjau Dari Kreativitas Siswa Pada Materi Larutan Penyangga Di SMA N 2 Sukoharjo Tahun Ajaran 2013/2014”. Jurnal Pendidikan Kimia. Vol.3 Tahun 2014, pp 89-97.

Ngalimun. (2013). Strategi dan Model Pembelajaran. Banjarmasin: Aswaja Presindo.

Riyanto, Yatim. (2012). Paradigma Baru Pembelajaran Sebagai Referensi bagi Pendidik dalam Implementasi Pembelajaran yang Efektif dan 
Berkualitas. Jakarta: Kencana Prenada Media Group.

Salim, Ali Rashid Alghafri and Hairul Nizam Bin Ismail. (2014). "The Effects of Integrating Creative and Critical Thinking on Schools Students' Thinking”. International Journal of Social Science and Humanity. Vol.4, No.6. pp. 518525.

Sapriya. (2009). Pendidikan IPS Konsep dan Pembelajaran. Bandung: PT Remaja Rosdakarya.

Sardjiyo dkk. (2007). Pendidikan IPS di SD. Jakarta: Universitas Terbuka.

Savery, John R. (2006). "Overview of Problem-based Learning: Definitions and Distinction”. IJPBLInterdisciplinary Journal of Problem-Based Learning. Vol.1 No.1. Spring 2006. pp. 9-20.

Siswono, Tatag Y.E. (2008). Model Pembelajaran Matematika Berbasis Pengajuan dan Pemecahan Masalah untuk Meningkatan Kemampuan Berpikir Kreatif. Surabaya: Unesa University Press.

Sohibi, Muh dan Joko Siswanto. (2012). "Pengaruh Pembelajaran Berbasis Masalah Dan Inkuiri Terbimbing Terhadap Kemampuan Berpikir Kritis Dan Kreatif Siswa". Jurnal Prodi Pendidikan Fisika IKIP PGRI Semarang. pp. 135-144.

Sugiyono. (2012). Metode Penelitian Kombinasi (Mixed Methods). Bandung: Alfabeta.

Suhanadji dan Waspodo Tjipto S. (2003). Pendidikan IPS. Surabaya: Insan Cendekia

Sukmadinata, Nana Saodih. 2013. Metode Penelitian Pendidikan. Bandung: Rosdakarya.

Sundayana, Rostina. 2015. Statistika Penelitian Pendidikan. Bandung: Alfabeta.

Suryanti, dkk. (2008). Model-Model Pembelajaran Inovatif. Surabaya: Unesa University Press

Susanto, Ahmad. (2012). Teori Belajar dan Pembelajaran. Jakarta: Kencana Prenada Media Group.

Tim Dosen Pengembang Ilmu Pengetahuan FIP Unesa. (2004). Pengantar Ilmu Pendidikan. Surabaya: Fakultas Ilmu Pendidikan Universitas Negeri Surabaya.

Trianto. (2007). Model-Model Pembelajaran Inovatif Berorientasi Konstruktivistik. Jakarta: Prestasi Pustaka Publisher.

(2009). Mendesain Model Pembelajaran InovatifProgresif: Konsep, Landasan, dan Implementasinya pada Kurikulum Tingkat
Satuan Pendidikan (KTSP). Jakarta: Kencana Prenada Media Group.

Walpole. (1995). Pengantar Statistika. Jakarta: Gramedia Pustaka Utama.

Warsono dan Hariyanto. (2012). Pembelajaran Aktif Teori dan Asesmen. Surabaya: PT Remaja Rosdakarya. 